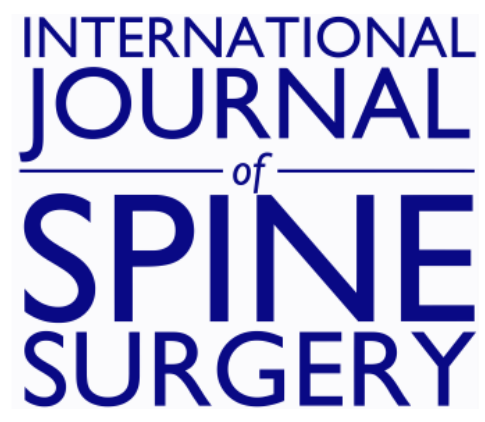

\title{
Stem Cells and Intervertebral Disc Regeneration Overview-- What They Can and Can't Do
}

Gianluca Vadalà, Luca Ambrosio, Fabrizio Russo, Rocco Papalia and Vincenzo Denaro

Int J Spine Surg 2021, 15 (s1) 40-53

doi: https://doi.org/10.14444/8054

http://ijssurgery.com/content/15/s1/40

This information is current as of April 26, 2023.

Email Alerts Receive free email-alerts when new articles cite this article. Sign up at:

http://ijssurgery.com/alerts

The International Journal of Spine Surgery

2397 Waterbury Circle, Suite 1,

Aurora, IL 60504, Phone: +1-630-375-1432

(C) 2021 ISASS. All Rights,Refserved 


\title{
Stem Cells and Intervertebral Disc Regeneration Overview-What They Can and Can't Do
}

\author{
GIANLUCA VADALÀ, MD, PHD, LUCA AMBROSIO, MD, FABRIZIO RUSSO, MD, ROCCO PAPALIA, \\ MD, PHD, VINCENZO DENARO, MD \\ Department of Orthopaedic and Trauma Surgery, Campus Bio-Medico University of Rome, Rome, Italy
}

\begin{abstract}
Background: Low back pain (LPB) is the main cause of disability worldwide with enormous socioeconomic burdens. A major cause of LBP is intervertebral disc degeneration (IDD): a chronic, progressive process associated with exhaustion of the resident cell population, tissue inflammation, degradation of the extracellular matrix and dehydration of the nucleus pulposus. Eventually, IDD may lead to serious sequelae including chronic LBP, disc herniation, segmental instability, and spinal stenosis, which may require invasive surgical interventions. However, no treatment is actually able to directly tackle IDD and hamper the degenerative process. In the last decade, the intradiscal injection of stem cells is raising as a promising approach to regenerate the intervertebral disc. This review aims to describe the rationale behind a regenerative stem cell therapy for IDD as well as the effect of stem cells following their implantation in the disc environment according to preclinical studies. Furthermore, actual clinical evidence and ongoing trials will be discussed, taking into account the future perspective and current limitations of this cutting-edge therapy.

Methods: A literature analysis was performed for this narrative review. A database search of PubMed, Scopus and ClinicalTrials.gov was conducted using "stem cells" combined with "intervertebral disc", "degeneration" and "regeneration" without exclusion based on publication date. Articles were firstly screened on a title-abstract basis and, subsequently, full-text were reviewed. Both preclinical and clinical studies have been included.

Results: The database search yielded recent publications from which the narrative review was completed.

Conclusions: Based on available evidence, intradiscal stem cell therapy has provided encouraging results in terms of regenerative effects and reduction of LBP. However, multicenter, prospective randomized trials are needed in order confirm the safety, efficacy and applicability of such a promising treatment.
\end{abstract}

Special Issue

Keywords: intervertebral disc degeneration, stem cell, disc regeneration, intradiscal injection, mesenchymal stem cells

\section{INTRODUCTION}

Low back pain (LBP) is the leading cause of disability worldwide and is estimated to affect up to $80 \%$ of individuals at least once in a lifetime. ${ }^{1}$ The prevalence of activity-limiting LBP is low during childhood but steeply increases with adolescence, when approximately $40 \%$ of teenagers experience an episode of LBP. ${ }^{2}$ However, LPB becomes significantly more common with aging, peaks in midlife and mainly affects the female and working populations. ${ }^{3}$ The social burden of LBP is enormous: the Global Burden of Disease study calculated that LBP alone was responsible for about 60.1 years lived with disability, an increment of more than $50 \%$ compared to $1990 .^{4}$ As a consequence, economic costs associated with the treatment of LBP account for a large portion of healthcare expenses. In 2018, approximately $\$ 90$ million were spent in the United
States for the diagnosis and management of LBP alone, with spinal fusion accounting for $7.1 \%$ of costs of hospital stays among all inpatient procedures. $^{5}$

A major cause of LBP is intervertebral disc degeneration (IDD): a chronic, progressive process associated with aging, ${ }^{6}$ genetic predisposition, ${ }^{7}$ smoking, ${ }^{8}$ diabetes, ${ }^{9}$ overweight, ${ }^{10}$ and additional risk factors (ie, heavy physical labor or inactivity, atherosclerosis of spinal vessels, inflammatory diseases ${ }^{11}$ ). During IDD, the increased catabolic activity along with the gradual reduction of functional cells (due to both cell apoptosis and the acquisition of a defective senescent phenotype) of the intervertebral disc (IVD) dramatically reduces its capacity to produce an adequate amount of extracellular matrix (ECM) and preserve its structural integrity. ${ }^{12}$ As a consequence, dehydration of the nucleus pulposus (NP) occurs with subsequent 
reduction of disc height and shock-absorbing capacity, thus leading to transmission of circumferential forces to the annulus fibrosus (AF) eventually resulting in AF tears which predispose to discogenic LBP, herniations and further degenerative changes. ${ }^{13}$

To date, the treatment of LBP and its sequelae remains an unsolved challenge, as neither conservative nor surgical strategies can directly tackle IDD. Therefore, a strenuous research effort is being made to develop minimally invasive approaches to hamper IDD or, ideally, regenerate the IVD. The use of stem cell-based treatments has been extensively investigated during the last 2 decades with promising results at both preclinical and clinical levels. ${ }^{14}$

The purpose of this review is to outline the rationale of a stem cell-based therapy for IDD and to discuss the main biological and clinical outcomes depicted by recent studies on the topic. Furthermore, principal limitations of this approach and challenges in the near future will be debated.

\section{THE RATIONALE OF A STEM CELL- BASED THERAPY FOR IDD}

During IDD, the number of healthy resident cells progressively decreases, with catabolic events predominating over normal tissue anabolism. ${ }^{15}$ Stem cells are undifferentiated cells able to self-renew and proliferate producing committed, differentiated elements that renovate the cell pool in a specific tissue. To date, stem cells have been isolated from several tissues where they reside in specialized microenvironments defined as niches. ${ }^{15}$ Therefore, stem cells can be harvested from multiple sources and transplanted into host tissues where they may differentiate into mature cells, secrete growth factors and cytokines to support resident cell activity, and/or recruit local progenitor cells to induce endogenous repair of the degenerated IVD. ${ }^{14}$ Nonetheless, these cells should be able to survive in the harsh degenerative IVD microenvironment, which is characterized by hypoxia, low glucose levels, acidic $\mathrm{pH}$, hyperosmolarity, inflammation, and mechanical loading. ${ }^{15}$

In order to exert a direct local effect and considering the avascular nature of the IVD, the main route of stem cell transplantation adopted in most studies is through a minimally invasive transannular intradiscal injection. Although considered reasonably safe, AF puncture has been shown to promote IDD as well as to increase the risk of disc herniation and endplate changes both in preclinical $^{16}$ and clinical studies. ${ }^{17}$ Therefore, an alternative transpedicular route to access the NP without violating the $\mathrm{AF}$ has been proposed for the administration of therapeutic agents inside the IVD. ${ }^{18}$ However, a recent study from Decante and colleagues $^{19}$ showed that both the transannular and the transpedicular approaches induced IDD as demonstrated by magnetic resonance imaging (MRI) and histological analysis in an ovine model. In addition, the transpedicular approach caused persistent endplate defects, with Schmorl-like herniations and osseous displacement within the NP. For this reason, further studies are needed to define the best route to safely approach the IVD in the clinical setting.

The application of several types of stem cells for IVD regeneration has been described in the literature, including mesenchymal stem cells (MSCs), induced pluripotent stem cells (iPSCs), embryonic stem cells, muscle-derived stem cells, hematopoietic stem cells, and olfactory mucosa stem cells. ${ }^{20}$ These cells may be transplanted either in an undifferentiated state, following an in vitro preconditioning and/or predifferentiation using diverse biological stimuli (e.g., growth factors, biomaterials, signaling molecules, IVD-like nutrition conditions) or modified to overexpress specific markers to achieve a discogenic phenotype before implantation. ${ }^{21-25}$ In the near future, the use of clustered regularly interspaced short palindromic repeat (CRISPR) genome editing may open new possibilities by directly inhibiting the expression of cytokine receptors or senescence markers or increasing the expression of matrix proteins in MSCs. ${ }^{26}$

MSCs harvested from the bone marrow (BMMSCs) and the adipose tissue (adipose-derived stem cells [ADSCs]) are the most widely investigated cell types for several reasons, including the ease of harvest, the extensive availability, the differentiation capacity into IVD-like cells, and the anabolic and anti-inflammatory potential in the site of transplantation. Although belonging to the same lineage, BM-MSCs and ADSCs are characterized by different biological properties and diverse responses to the IVD microenvironment that have been outlined by recent investigations. ${ }^{15}$ BM-MSCs have been demonstrated to better tolerate the hypoxic IVD environment as low $\mathrm{O}_{2}$ upregulates the hypoxiainducible factor $1 \alpha$ and yes-associated protein pathways resulting in increased proliferation, stem- 
ness preservation, and protection from apoptosis. $^{27,28}$ On the other hand, in a recent in vitro study conducted by Binch and colleagues, ${ }^{29}$ ADSCs cultured in an IDD-mimicking media $\left(5 \% \mathrm{O}_{2}\right.$ and preconditioning with a proinflammatory stimulus) showed significantly higher levels of pain-associated neurotrophic and angiogenic factors in ADSC cultures compared to BM-MSCs, which may in turn promote neurovascular invasion of the degenerated IVD and thus contribute to discogenic LBP. However, when cultured in IVD-like hyperosmolar conditions (400 mOsm), ADSCs have demonstrated a higher expression of NP cell differentiation markers as well as ECM components through epigenetic regulation. $^{30}$

Recent studies have identified a population of progenitor cells exhibiting MSC markers and properties within the AF, the NP, and the cartilaginous endplates in both healthy and degenerative IVDs. ${ }^{31}$ These cells are characterized by the specific expression of angiopoietin-1 receptor and diasiloganglioside 2 and have showed a higher proliferative capacity in hypoxic and acidic conditions and an increased chondrogenic differentiation potential compared to other MSCs in vitro. ${ }^{32}$ Rather than a source for stem cell harvest and subsequent transplantation, IVD progenitor cells may be involved in endogenous tissue repair upon activation, recruitment, and nucleopulpogenic differentiation under the stimulus of growth factors, chemokines, and cytokines released by locally injected stem cells. ${ }^{14}$

iPSCs are pluripotent, highly proliferating stem cells that are directly generated from somatic mature cells through genetic reprogramming in order to acquire a specific phenotype. ${ }^{33}$ In several studies, iPSCs have been successfully reprogrammed in vitro towards NP-like, ${ }^{34}$ notochordal cell-like, ${ }^{35}$ or MSC-like phenotypes ${ }^{36}$ able to express NPspecific markers and support resident cells both in vitro and in vivo. However, the high costs required by genetic manipulation and safety concerns regarding iPSC tumorigenesis potential still limit their application in the clinical setting.

\section{THE EFFECT OF STEM CELLS IN THE DEGENERATIVE IVD ENVIRONMENT}

\section{Differentiation Into IVD-Like Cells}

The acquisition of a NP-like phenotype and the consequent capacity to synthesize novel ECM has been originally proposed as the most likely regen- erative effect of stem cells after intradiscal implantation. This capacity has been demonstrated by several preclinical studies, ${ }^{37-39}$ although prolonged cell survival in the hostile IVD microenvironment remains controversial. Indeed, several in vitro and in vivo reports have showed that stem cells become rapidly undetectable soon after or a few weeks following transplantation as a consequence of nutrient deprivation and low $\mathrm{pH}$ as well as due to the pressure generated during the procedure itself. ${ }^{37,38,40}$ In a recent study from Henriksson et al, ${ }^{41}$ iron sucrose-labelled autologous BM-MSCs were injected in the IVDs of 4 patients subsequently undergoing discectomy and fusion surgery. The results showed that viable MSCs and their progeny were retrieved in harvested IVD tissues up to 8 months postinjection as both large cell clusters and solitary cells.

\section{Support of Resident Cell Activity}

According to numerous preclinical studies, stem cells are able to stimulate resident IVD cells through the secretion of several growth factors, chemokines, ECM components, and anti-inflammatory mediators via a paracrine mechanism. Indeed, several in vitro investigations ${ }^{42}$ have reported that the MSC coculture with NP cells was associated with an increase of cell proliferation and ECM synthesis, ${ }^{43,44}$ with a reduction of cell senescence and metalloproteinase levels. In a recent study from Hingert et $\mathrm{al}^{45}$ a secretome analysis conducted on BM-MSC conditioned media revealed 753 unique peptides, mostly represented by ECM proteins $(20.16 \%)$, enzymes $(22.48 \%)$, glycoproteins and proteoglycans $(12.4 \%)$, and growth factors and their modulators $(6.98 \%$, including vascular endothelial growth factor, bone morphogenetic protein 1, connective tissue growth factor, insulin-like growth factor binding protein, metalloproteinase inhibitors, antiapoptotic factors, and several more. Furthermore, when cultured in hypoxic conditions $\left(5 \% \mathrm{O}_{2}\right), \mathrm{BM}-\mathrm{MSC}$ s have shown an incremented expression of genes involved in chondrogenic differentiation (ACAN, KRT19, BARX1), immunomodulation (CXCL5, SFN), and cell survival and proliferation (GPX3, TXNIP) compared to BMMSCs cultured under atmospheric $\mathrm{O}_{2}{ }^{46}$

In an investigation from Chen et al, ${ }^{47} \mathrm{BM}-\mathrm{MSCs}$ and NP cells were cocultured under static mechanical loading. Compared to NP cells alone, BMMSCs significantly reduced compression-induced 
NP cell apoptosis in the coculture group via the inhibition of the mitochondrial pathway. Indeed, BM-MSCs decremented reactive oxygen species (ROS) and proapoptotic marker (caspase-3, caspase-9, cytochrome c) levels and maintained mitochondrial membrane potential and integrity. ${ }^{47}$

Furthermore, MSCs may improve the mechanical properties of NP cells by directly reducing cellular and matrix stiffness. Indeed, Liu and colleagues ${ }^{48}$ have shown that the coculture of MSCs with degenerated NP cells significantly decreased the mechanical moduli of the latter, while increasing cell proliferation and both collagen type II and aggrecan expression. These changes were associated with the upregulation of stromal cell-derived factor-1 and its receptor, CXC receptor 4, which have been previously correlated with stem cell migration and homing.

The anabolic and anti-inflammatory effects of MSCs may not be restricted to the IVD only but could also positively affect surrounding tissues. In a study from James et $\mathrm{al}^{49}$ the intradiscal injection of MSCs following a stab AF lesion in an ovine model prevented fibrotic and adipose tissue deposition within the multifidus muscle, whilst increasing the levels of tumor necrosis factor- $\alpha$ (TNF- $\alpha$ ) and transforming growth factor $\beta$ at the site of injury.

\section{Immunomodulation}

During IDD, several proinflammatory cytokines secreted by IVD resident cells and immune system cells foster ECM breakdown and promote chemotaxis, neoangiogenesis, and the release of additional cytokines, thus perpetrating the inflammatory response. ${ }^{50}$ The main mediators involved in this process include several interleukins (IL; among which IL- $1 \beta$ plays the most important role), TNF$\alpha$, interferon- $\gamma$, prostaglandin $\mathrm{E}_{2}$, and multiple chemokines. ${ }^{51,52}$ Collectively, these molecules are able to trigger cell apoptosis, senescence, and autophagy as well as upregulating the release of numerous metalloproteinases, including the matrix metalloproteinases and the a disintegrin and metalloproteinase with thrombospondin motifs families, as well as ROS. ${ }^{50}$ Furthermore, inflammation may significantly affect MSC metabolic activity, differentiation, and viability. In a recent study from Borem et al, ${ }^{53}$ ADSCs and amnion-derived MSCs were cultured under proinflammatory conditions with or without the supplementation of IL-1 $\beta$ and TNF- $\alpha$. While the former showed increased prolif- eration with upregulation of proinflammatory cytokines and enhanced osteogenesis, the latter displayed an increment of anti-inflammatory cytokines and improved chondrogenesis. In addition, exposure to inflammatory stimuli in vitro has been demonstrated to reduce the expression of aggrecan and SOX9 and to increase cell apoptosis in NPMSCs, as well as promoting neurogenic differentiation which may contribute to IVD reinnervation and the development of chronic LBP. ${ }^{54}$

However, previous studies have also demonstrated that MSCs are capable of secreting antiinflammatory cytokines, anticatabolic mediators, and growth factors when cultured under IDD-like conditions both in vitro ${ }^{55}$ and ex vivo, ${ }^{56}$ hence demonstrating an immunomodulatory effect on resident IVD cells. According to recent investigations, MSCs may exert this anti-inflammatory effect by primarily inhibiting the p38 mitogen-activated protein kinase signaling pathway. ${ }^{57}$ Furthermore, BM-MSCs have been shown to tackle mitochondrial damage subsequent to increased oxidative stress through mitophagy, even if this response was effective only at an early stage, with prolonged oxidative exposure causing apoptosis. ${ }^{58}$ Therefore, mitophagy may be a key factor in protecting MSCs from the hostility of the degenerative microenvironment.

A summary of the regenerative effects of stem cells following transplantation in the disc environment is depicted in Figure 1.

\section{CURRENT CLINICAL EVIDENCE}

The consistent body of preclinical research investigating the use of stem cells for IVD regeneration has provided the basis for several clinical studies with promising results. Safety and feasibility of this approach have been validated in 7 cohort studies $^{59-66}$ on individuals affected by discogenic LBP ( $\geq$ stage II according to Pfirrmann grading) not responsive to standard conservative treatments. Cell sources used in these studies included autologous $\mathrm{ADSCs}^{62}$, ADSCs from the stromal vascular fraction (SVF), ${ }^{63}$ bone marrow aspirate concentrate (BMAC), ${ }^{60,61}$ and autologous ${ }^{59,65}$ and allogeneic ${ }^{64}$ BM-MSCs and allogeneic mesenchymal precursor cells $(\mathrm{MPCs})^{66}$ at a highly variable concentrations $\left(10-60 \times 10^{6}\right.$ in $\left.1-3 \mathrm{~mL}\right)$ and delivered via a fluoroscopic-guided transannular intradiscal injection. Collectively, most patients $(65.4 \%)$ reported an improvement in Oswestry disability index (ODI) 


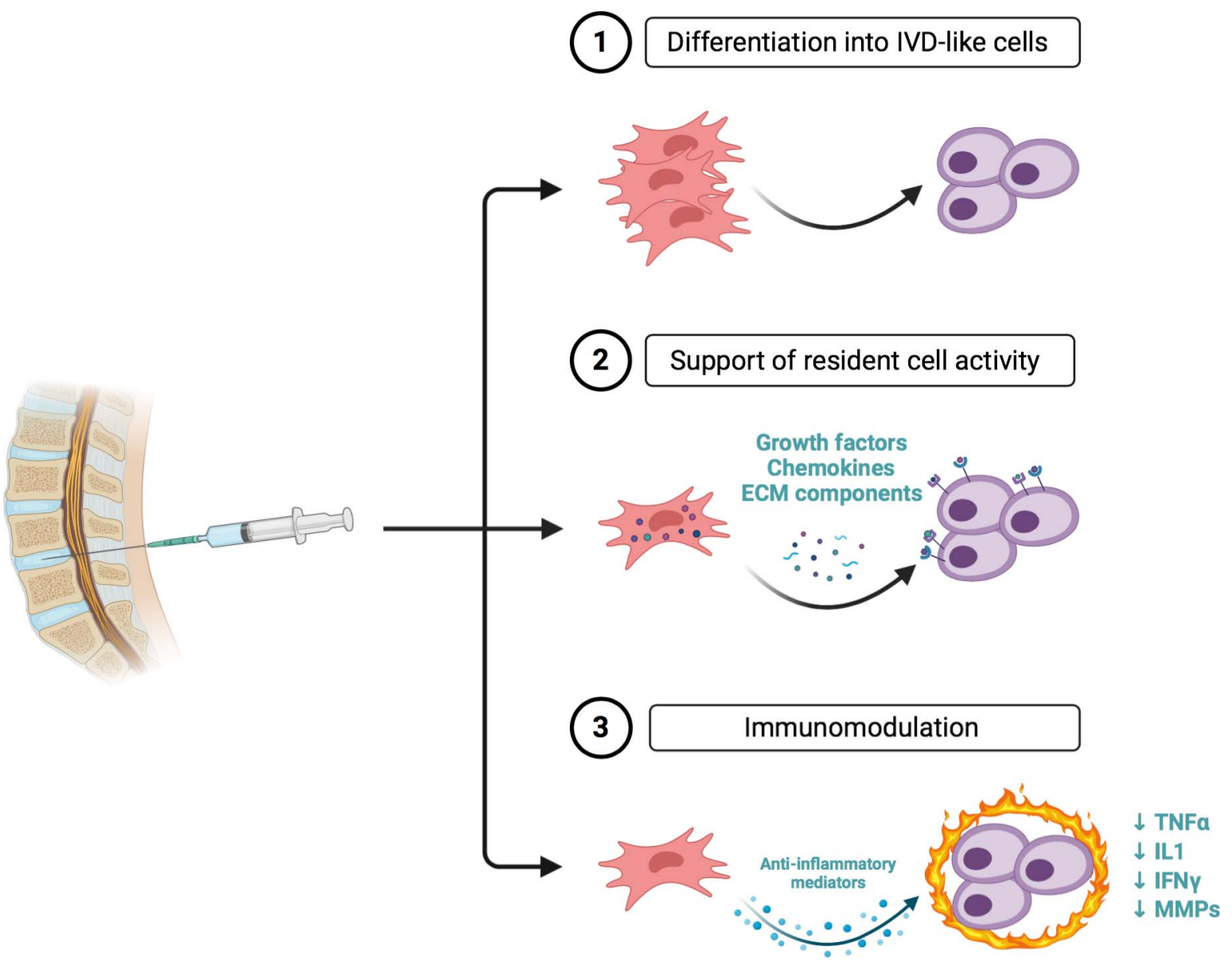

Figure 1. The main effects of stem cells following transplantation into the intervertebral disc. IVD, intervertebral disc; ECM, extracellular matrix; TNF $\alpha$, tumor necrosis factor- $\alpha$; IL, interleukin; IFN, interferon; MMP, matrix metalloproteinase. Created with BioRender.com.

and visual analogue scale (VAS) throughout a follow-up of 6-72 months and in one study, ${ }^{60}$ $30.77 \%$ of patients reported an improvement of $\geq$ 1 Pfirrmann grade at 12 months. None of these studies reported serious adverse events. ${ }^{26}$ However, the low number of participants (5-26) and the high variability in cell source and concentration across the aforementioned studies must be taken into account.

The first clinical investigation reporting the results of an intradiscal injection of autologous BM-MSCs was performed by Orozco and colleagues. ${ }^{59}$ In this pilot phase I study, the authors included 10 patients affected by LBP not responsive to conservative treatment for $\geq 6$ months associated with 1- or 2-level IDD with intact AF as demonstrated by discography. Following inclusion in the study, patients underwent bone marrow harvesting from the iliac crest. BM-MSCs were then isolated and expanded in vitro until passage 3. Subsequently, 3-4 weeks after the first procedure, patients received an intradiscal injection of BM-MSCs $\left(10 \pm 5 \times 10^{6}\right.$ per disc) under slight sedation and were discharged 2 hours later. Patients were reevaluated at 1 week and at 3, 6, and 12 months after the injection. LBP and associated disability were assessed at each follow-up visit using the VAS and ODI scales. Disc height and hydration were examined at 6 and 12 months with MRI. Both VAS and ODI were significantly reduced at 3 months following MSC transplantation, with a modest additional improvement at 6 and 12 months and a reported efficacy of $71 \%$. No relevant change of disc height was noted, although NP water content was significantly increased at 12 months. No adverse reactions were reported. Despite the small number of patients, the absence of a control group, and the short follow-up, this study demonstrated for the first time that BMMSC intradiscal transplantation was a safe procedure with a promising role for the treatment of IDD. 
Pettine et $\mathrm{al}^{60,61}$ conducted a prospective nonrandomized cohort study including 26 patients affected by chronic LBP unresponsive to conservative treatment with a modified Pfirrmann score of 47 at MRI. According to the number of levels involved, patients were divided in 2 groups receiving 1- or 2-level intradiscal injection. Differently from other studies, the authors proposed a 1-stage procedure with bone marrow harvesting, intraoperative processing and production of BMAC, and intradiscal transplantation. Patients were reviewed at 3, 6, 12, and 24 months; VAS and ODI were assessed at each follow-up visit. MRI was obtained at 12 months and the Pfirrmann score of treated IVDs was recalculated. The results showed that BMAC was able to reduce pain and disability at each time point (71\% VAS and $64 \%$ ODI improvement at 2 years), with approximately $30 \%$ of patients reporting an improvement of the Pfirrmann score at follow-up MRI. ${ }^{61}$ Five patients did not respond to the treatment and 2 of these underwent a reinjection at 6 months, with a significant improvement at 12 months. No adverse events, including heterotopic ossifications or osteophyte development, were noted. Reported total nucleated cell concentration was $121 \pm 10 \times 10^{6} / \mathrm{mL}$, although less than $0.005 \%$ expressed MSC phenotypic markers. Nonetheless, patients receiving a higher number of cells experienced a significantly faster and greater reduction of ODI and VAS. Compared to autologous or allogeneic expanded MSCs, the use of BMAC was associated with reduced operative time, decreased costs and risks of infection, disease transmission, or simple mismatch. ${ }^{60}$ However, as stem cell quantity and quality in BMAC largely depend on individuals' age and harvesting procedure, it is not possible to generalize the results and to compare them with other studies using MSCs alone. ${ }^{67}$

Elabd and coauthors ${ }^{65}$ performed a long-term safety and feasibility study on 5 patients undergoing single-level intradiscal injection of autologous BM-MSCs. Individuals with LBP not responsive to conservative treatment for $\geq 3$ months associated with IDD and/or a positive provocative discography were included. Before receiving the injection, bone marrow was obtained and BM-MSCs were isolated and cultured in hypoxic conditions $(5 \%$ $\mathrm{O}_{2}$ ). On the day of the procedure, BM-MSCs were resuspended in autologous platelet lysate until reaching a volume of $0.25-1 \mathrm{~mL}$. Cell number significantly varied among the participants (15.1$\left.51.6 \times 10^{6}\right)$. Patients were reviewed at 4-6 years with a physical examination, an MRI, and a quality-of-life questionnaire. The majority of patients reported an improvement in quality of life, strength, and mobility, as well as an apparent reduction of disc protrusion. However, the restricted sample size, the lack of validated endpoint measurements, and the absence of intermediate time points significantly limit the outcomes of the study.

Kumar et $\mathrm{al}^{62}$ conducted another single-arm phase I clinical trial including 10 patients with LBP not responding to conventional treatment for $\geq 3$ months, signs of IDD (Pfirrmann score 3-4 at 1 or 2 levels), and discogenic etiology of LBP as confirmed by discography. Three weeks before injection, participants underwent abdominal liposuction; samples were then transferred to a laboratory were ADSCs were isolated and expanded in vitro until passage 3. ADSCs were then injected in the affected IVDs in combination with a hyaluronic acid (HA) derivative, namely $1 \%$ Tissuefill $^{\circledast}$. Two MSC doses were tested: 5 patients received $20 \times 10^{6}$ cells per disc and 5 patients received $40 \times 10^{6}$ cells per disc. Patients were reexamined at 1 week and at 3, 6, and 12 months after the injection, with VAS, ODI and Short Form 36 (SF-36) being evaluated at each time point and spine imaging (lumbar spine $\mathrm{x}$-ray and MRI) at 1 , 6 , and 12 months. 6 of 10 patients were demonstrated to reach the final treatment success milestone (reduction $\geq 50 \%$ in VAS and ODI compared to pretreatment). No significant difference was found between the 2 doses. Additionally, no decrease in disc height and no change in Pfirrmann score were reported, with 3 patients showing signs of increased NP hydration at the final follow-up. As in previous studies, no adverse events were reported. Potential causes of treatment failure were evaluated in 4 patients, 2 of whom were overweight, 1 presenting with a L4-L5 grade I spondylolisthesis and facet joint arthritis, and another with depressive symptoms. Therefore, authors pointed out that accurate patient selection may be crucial for achieving success in intradiscal stem cell treatments.

In an open-label prospective study, Comella et $\mathrm{al}^{63}$ evaluated the effect of an intradiscal injection of autologous SVF blended with platelet-rich plasma (PRP) in patients with LBP not responsive to 
conservative treatment for $\geq 6$ months due to 1-, 2-, or 3-level IDD as demonstrated by MRI. Patients enrolled underwent a 1-stage procedure with lipoaspirate harvesting, intraoperative SVF extraction, PRP preparation from a whole blood sample, and intradiscal injection of $1 \mathrm{~mL} \mathrm{SVF} / \mathrm{PRP}$ (containing circa $30-60 \times 10^{6}$ cells). Patient were evaluated at 2 and 6 months. Low back range of motion, VAS, ODI, present pain index (PPI), Beck depression inventory (BDI), Short Form McGill pain questionnaire (SM-MPQ), Short Form 12 (SF-12), and the Dallas pain questionnaire were assessed. Overall, patients reported increased lumbar flexion, significant reduction of VAS and PPI at 2 and 6 months, significant improvement of SM-MPQ and SF-12 at 6 months, and no statistically significant change of BDI and ODI. However, the notable variability in cell concentration and the short follow-up importantly limit the possibility to state the efficacy of this methodology for IVD regeneration.

The first randomized controlled trial (RCT) to evaluate the efficacy of an intradiscal stem cell therapy for IDD was conducted by Noriega and colleagues. ${ }^{64}$ In this phase I-II trial, 24 patients with chronic LBP unresponsive to conservative treatment for $\geq 6$ months associated with 1 - or 2 level IDD (Pfirrmann score 2-4) were randomly allocated to the experimental or the control group. The former received an intradiscal injection of allogeneic BM-MSCs $\left(25 \times 10^{6}\right.$ per disc $)$, while the latter received a sham infiltration within the paravertebral musculature. Patients were followed up at 1 week and 3, 6, and 12 months after the injection. VAS, ODI, and SF-12 were assessed at each time point, and MRI was performed at 6 and 12 months. A significant improvement in VAS and ODI was documented in the control group at 3 months and was maintained until the last followup. Although no significant difference regarding disc height and water content was reported between the 2 groups, a statistically significant improvement in Pfirrmann score was encountered in treated disc.

Recently, Amirdelfan et al ${ }^{66}$ have reported the results of a multicenter RCT investigating the safety and efficacy of the intradiscal administration of stromal precursor antigen-3 (STRO-3)+ MPCs combined with HA. In this phase II study, 100 patients affected by chronic LBP ( $\geq 6$ months) associated with 1-level moderate IDD (modified
Pfirrmann score 3-6) were randomized to receive $6 \times$ $10^{6}$ MPCs with $1 \%$ HA, $18 \times 10^{6}$ MPCs with $1 \%$ HA, $1 \%$ HA only or sham. Patients were reviewed at 1, 3, 6, 12, 24 and 36 months following the injection. VAS, ODI, SF-36 and Work Productivity and Activity Index (WPAI) were evaluated at each timepoint, while MRI was performed at 6 months. Patients treated with intradiscal MPCs showed significant improvements in pain and function at various timepoints, although no apparent change in modified Pfirrmann score was evident among groups.

The characteristics of clinical investigations reporting the effect of MSCs for IVD regeneration are depicted in Table 1.

To date, 10 clinical trials using stem cells for IVD regeneration are ongoing (Table 2). Of these, 7 (NCT02412735, ${ }^{68}$ NCT03340818, ${ }^{69}$ NCT0369222 $1,{ }^{70}$ NCT03737461, ${ }^{71}$ NCT03461458, ${ }^{72}$ NCT04759105, ${ }^{73}$ EudraCT no. 2019-002749-40 74 ) are RCTs with a control group receiving a sham injection, while the remaining 3 (NCT03912454, ${ }^{75}$ NCT04414592, ${ }^{76}$ NCT04499105 ${ }^{77}$ ) are open-label cohort studies. Inclusion criteria generally admit adult individuals affected by chronic LBP not responsive to conservative treatments and with radiological evidence (mostly confirmed by MRI according to the Pfirrmann grading) of single or multilevel IDD. However, one of these studies (NCT04414592 $2^{75}$ ) will evaluate the use of stem cells in patients with sciatica due to lumbar disc herniation following fully endoscopic lumbar discectomy. These clinical trials will test MSCs from various sources, including autologous BM-MSCs (NCT03692221, ${ }^{70}$ NCT04759105, ${ }^{73} \mathrm{Eu}-$ draCT no. 2019-002749-40 ${ }^{74}$ ), allogeneic BM-MSCs (NCT02412735, ${ }^{68} \mathrm{NCT} 03737461^{71}$ ) and autologous ADSCs (NCT03461458 72 ), with 2 studies (NCT04414592, ${ }^{76}$ NCT04499105 77 ) investigating the regenerative potential of allogeneic human umbilical cord mesenchymal stem cells. Cell concentration among the studies is highly variable $\left(2-25 \times 10^{6}\right.$ cells $)$ and in one trial (NCT02412735 $5^{68}$ ) MSCs will be delivered in a $1 \%$ hyaluronic acid solution instead of saline. Moreover, 2 trials (NCT03340818, ${ }^{69}$ NCT03912454 ${ }^{75}$ ) will use BMAC. The objective of these studies is to evaluate the efficacy of an intradiscal transplantation of MSCs mainly in terms of safety and improvement of pain and disability. In addition, assessment of IVD structural changes with $\mathrm{X}$-ray and MRI will be investigated, as well as the use 
Vadala et al.

Table 1. Previous cohort studies investigating the application of stem cells for intervertebral disc regeneration.

\begin{tabular}{|c|c|c|c|c|c|c|c|c|}
\hline Authors & $\begin{array}{l}\text { Type of } \\
\text { Study }\end{array}$ & Year & $\begin{array}{l}\text { No. of } \\
\text { Patients }\end{array}$ & Inclusion Criteria & Cell Source & Cell Concentration & Outcomes & Follow-Up \\
\hline Orozco et al ${ }^{59}$ & Prospective & 2011 & 10 & $\begin{array}{l}\text { 18-65 yo with chronic } \\
\text { LBP }(\geq 6 \text { mo) not } \\
\text { responsive to } \\
\text { conservative } \\
\text { treatment with } \\
\text { radiological signs of } \\
\text { IDD and intact AF }\end{array}$ & $\begin{array}{l}\text { Autologous } \\
\text { BM-MSCs }\end{array}$ & $10 \pm 5 \times 10^{6}$ cells & $\begin{array}{l}\text { - Improvement in } \\
\text { VAS, ODI, and } \\
\text { SF36 } \\
\text { - Change in T2 } \\
\text { MRI signal in- } \\
\text { tensity within } \\
\text { the NP }\end{array}$ & $12 \mathrm{mo}$ \\
\hline Pettine et $\mathrm{al}^{60,61}$ & Prospective & 2015 & 26 & $\begin{array}{l}\text { Patients with chronic } \\
\text { LBP }(\geq 6 \text { mo) not } \\
\text { responsive to } \\
\text { conservative } \\
\text { treatment (Pfirrmann } \\
\text { IV-VII) }\end{array}$ & $\begin{array}{c}\text { Autologous } \\
\text { BMAC }\end{array}$ & & $\begin{array}{l}\text { - Improvement in } \\
\text { VAS and ODI } \\
\text { - Change in T2 } \\
\text { MRI signal in- } \\
\text { tensity within } \\
\text { the NP } \\
\text { - Progression to } \\
\text { surgery }\end{array}$ & $24 \mathrm{mo}$ \\
\hline Elabd et al ${ }^{65}$ & Prospective & 2016 & 5 & $\begin{array}{l}\text { 18-65 yo with chronic } \\
\text { LBP }(\geq 3 \mathrm{mo}) \text { not } \\
\text { responsive to } \\
\text { conservative } \\
\text { treatment and a } \\
\text { positive discography }\end{array}$ & $\begin{array}{l}\text { Autologous } \\
\text { BM-MSCs }\end{array}$ & $\begin{array}{l}15.1-51.6 \times 10^{6} \\
\text { cells }+ \text { autologous } \\
\text { platelet lysate }\end{array}$ & $\begin{array}{l}\text { - Improvement in } \\
\text { clinical symp- } \\
\text { toms and quali- } \\
\text { ty of life } \\
\text { - Change in MRI } \\
\text { signal intensity } \\
\text { within the NP }\end{array}$ & $48-72 \mathrm{mo}$ \\
\hline Kumar et $\mathrm{al}^{62}$ & Prospective & 2017 & 10 & $\begin{array}{l}\text { 19-70 yo with chronic } \\
\text { LBP }(\geq 3 \text { mo) not } \\
\text { responsive to } \\
\text { conservative } \\
\text { treatment (Pfirrmann } \\
\text { III-IV) }\end{array}$ & $\begin{array}{l}\text { Autologous } \\
\text { ADSCs }\end{array}$ & $\begin{array}{c}25 \times 10^{6} \text { cells }+ \\
\text { HA derivative } \\
40 \times 10^{6} \text { cells }+ \\
\text { HA derivative }\end{array}$ & $\begin{array}{l}\text { - Rate of SAE } \\
\text { - Improvement in } \\
\text { VAS, ODI, and } \\
\text { SF36 } \\
\text { - Change in MRI } \\
\text { signal intensity } \\
\text { within the NP }\end{array}$ & $12 \mathrm{mo}$ \\
\hline Comella et al ${ }^{63}$ & Prospective & 2017 & 15 & $\begin{array}{l}\text { 18-90 yo with chronic } \\
\text { LBP }(\geq 6 \text { mo) not } \\
\text { responsive to } \\
\text { conservative } \\
\text { treatment and intact } \\
\text { AF }\end{array}$ & SVF & $\begin{array}{l}30-60 \times 10^{6} \text { cells in } \\
1-3 \mathrm{~mL}+ \\
\text { autologous } \mathrm{PRP}\end{array}$ & $\begin{array}{l}\text { - Rate of SAE } \\
\text { - Improvement in } \\
\text { VAS, PPI, BDI, } \\
\text { ODI, SF12, and } \\
\text { Dallas pain } \\
\text { questionnaire }\end{array}$ & $6 \mathrm{mo}$ \\
\hline Noriega et al ${ }^{64}$ & $\mathrm{RCT}$ & 2017 & 24 & $\begin{array}{l}\text { 18-75 yo with chronic } \\
\text { LBP }(\geq 6 \text { mo not } \\
\text { responsive to } \\
\text { conservative } \\
\text { treatment with } \\
\text { radiological signs of } \\
\text { IDD and intact AF }\end{array}$ & $\begin{array}{l}\text { Allogeneic } \\
\text { BM-MSCs }\end{array}$ & $\begin{array}{l}25 \times 10^{6} \text { cells in } 2 \\
\mathrm{~mL} \text { vs Sham } \\
\text { infiltration }\end{array}$ & $\begin{array}{l}\text { - Improvement in } \\
\text { VAS, ODI, and } \\
\text { SF12 } \\
\text { - Change in T2 } \\
\text { MRI signal in- } \\
\text { tensity within } \\
\text { the NP }\end{array}$ & $12 \mathrm{mo}$ \\
\hline Amirdelfan et al ${ }^{66}$ & $\mathrm{RCT}$ & 2020 & 100 & $\begin{array}{l}>18 \text { yo with chronic } \\
\text { LBP }(\geq 6 \text { mo) not } \\
\text { responsive to } \\
\text { conservative } \\
\text { treatment with } \\
\text { moderate IDD } \\
\text { (modified Pfirmann } \\
\text { III-VI) }\end{array}$ & $\begin{array}{l}\text { Allogeneic } \\
\text { STRO-3 } \\
\text { MPCs }\end{array}$ & $\begin{array}{l}8 \times 10^{6} \text { cells }+1 \% \\
\text { HA vs } 16 \times 10^{6} \\
\text { cells }+1 \% \text { HA } v s \\
1 \% \text { HA only vs } \\
\text { Sham infiltration }\end{array}$ & $\begin{array}{l}\text { - Rate of SAE } \\
\text { - Improvement in } \\
\text { VAS, ODI, } \\
\text { SF36 and } \\
\text { WPAI } \\
\text { - Change in T2 } \\
\text { MRI signal in- } \\
\text { tensity within } \\
\text { the NP }\end{array}$ & $36 \mathrm{mo}$ \\
\hline
\end{tabular}

Abbreviations: ADSCs, adipose-derived stem cells; AF, annulus fibrosus; BDI, Beck Depression Inventory; BM-MSCs, bone marrow-derived mesenchymal stem cells; BMAC, bone marrow aspirate concentrate; HA, hyaluronic acid; IDD, intervertebral disc degeneration; LBP, low back pain; MPCs, mesenchymal precursor cells; MRI, magnetic resonance imaging; NP, nucleus pulposus; ODI, Oswestry Disability Index; PPI, present pain intensity; PRP, platelet-rich plasma; RCT, randomized controlled trial; SAE, serious adverse events, SF, Short Form Health Survey; STRO-3, stromal precursor antigen-3; SVF, stromal vascular fraction; T2, T2-weighted imaging; VAS, visual analog scale; WPAI, Work Productivity and Activity Index; yo, year-old. 
Table 2. Ongoing clinical trials investigating the application of stem cells for intervertebral disc regeneration.

\begin{tabular}{|c|c|c|c|c|c|c|c|c|c|}
\hline Identifying No. & Year & Design & $\begin{array}{l}\text { No. of } \\
\text { Patients }\end{array}$ & Inclusion Criteria & Cell Source & $\begin{array}{c}\text { Cell } \\
\text { Concentration }\end{array}$ & Primary Outcome & $\begin{array}{l}\text { Secondary } \\
\text { Outcomes }\end{array}$ & $\begin{array}{c}\text { Follow- } \\
\text { Up }\end{array}$ \\
\hline NCT02412735 68 & 2015 & $\mathrm{RCT}$ & 404 & $\begin{array}{l}\geq 18 \text { yo with } \\
\text { chronic LBP }(\geq 6 \\
\text { mo) not } \\
\text { responsive to } \\
\text { conservative } \\
\text { treatment } \\
\text { (Pfirrmann III-VI) }\end{array}$ & $\begin{array}{l}\text { Allogeneic } \\
\text { BM-MSCs }\end{array}$ & $\begin{array}{l}6 \times 10^{6} \text { cells } \\
\text { in } 2 \mathrm{~mL} \\
6 \times 10^{6} \text { cells } \\
\text { in } 2 \mathrm{~mL} \\
\text { HA }\end{array}$ & $\begin{array}{l}\text { Improvement in } \\
\text { VAS, ODI and no } \\
\text { posttreatment } \\
\text { interventions }\end{array}$ & $\begin{array}{l}\text { - Improve- } \\
\text { ment in pain } \\
\text { and func- } \\
\text { tionality } \\
\text { - Time to first } \\
\text { intervention }\end{array}$ & $24 \mathrm{mo}$ \\
\hline NCT03340818 69 & 2017 & $\mathrm{RCT}$ & 60 & $\begin{array}{l}\text { 18-55 yo with } \\
\text { chronic LBP }(\geq 6 \\
\text { mo) not } \\
\text { responsive to } \\
\text { conservative } \\
\text { treatment with } \\
\text { radiological signs } \\
\text { of IDD }\end{array}$ & $\begin{array}{c}\text { Autologous } \\
\text { BMAC }\end{array}$ & & $\begin{array}{l}\text { Improvement in } \\
\text { VAS and ODI }\end{array}$ & $\begin{array}{l}\text { - Improve- } \\
\text { ment in pain } \\
\text { and disabili- } \\
\text { ty } \\
\text { - Medication } \\
\text { usage } \\
\text { - Adjunct } \\
\text { therapy }\end{array}$ & $12 \mathrm{mo}$ \\
\hline NCT03692221 70 & 2018 & $\mathrm{RCT}$ & 24 & $\begin{array}{l}\text { 18-80 yo with } \\
\text { chronic LBP }(\geq 6 \\
\text { mo) not } \\
\text { responsive to } \\
\text { conservative } \\
\text { treatment } \\
\text { (Pfirrmann III-V) }\end{array}$ & $\begin{array}{l}\text { Autologous } \\
\text { BM-MSCs }\end{array}$ & $\begin{array}{l}2 \times 10^{6} \text { cells } \\
\text { in } 1-2 \mathrm{~mL} \\
4 \times 10^{6} \text { cells } \\
\text { in } 1-2 \mathrm{~mL}\end{array}$ & Rate of SAE & $\begin{array}{l}\text { - Improve- } \\
\text { ment in } \\
\text { VAS, ODI, } \\
\text { and SF-36 } \\
\text { - Change in } \\
\text { T2 MRI sig- } \\
\text { nal intensity } \\
\text { within the } \\
\text { NP }\end{array}$ & $12 \mathrm{mo}$ \\
\hline NCT03737461 71 & 2018 & $\mathrm{RCT}$ & 112 & $\begin{array}{l}\text { 18-60 yo with } \\
\text { chronic LBP }(\geq 3 \\
\text { mo) not } \\
\text { responsive to } \\
\text { conservative } \\
\text { treatment with } \\
\text { single-level IDD } \\
\text { (Pfirrmann IV- } \\
\text { VII) }\end{array}$ & $\begin{array}{l}\text { Allogeneic } \\
\text { BM-MSCs }\end{array}$ & $\begin{array}{l}20 \pm 5 \times 10^{6} \\
\text { cells in } 2 \\
\mathrm{~mL}\end{array}$ & $\begin{array}{l}\text { Improvement in } \\
\text { VAS and ODI }\end{array}$ & $\begin{array}{l}\text { - Improve- } \\
\text { ment in SF- } \\
\text { 36, disabili- } \\
\text { ty, and qual- } \\
\text { ity of life } \\
\text { - Use of pain- } \\
\text { killers } \\
\text { - Measure of } \\
\text { LBP } \\
\text { - Employment } \\
\text { and work } \\
\text { status } \\
\text { - Change in } \\
\text { T2 MRI sig- } \\
\text { nal intensity } \\
\text { within the } \\
\text { NP } \\
\text { - Evaluation } \\
\text { of costs } \\
\text { - Immune re- } \\
\text { sponse } \\
\text { - SAE }\end{array}$ & $24 \mathrm{mo}$ \\
\hline NCT03461458 & 2018 & $\mathrm{RCT}$ & 12 & $\begin{array}{l}\geq 18 \text { yo with } \\
\text { chronic LBP }(\geq 3 \\
\text { mo) not } \\
\text { responsive to } \\
\text { conservative } \\
\text { treatment } \\
\text { (Pfirrmann III- } \\
\text { VI) }\end{array}$ & $\begin{array}{l}\text { Autologous } \\
\text { ADSCs }\end{array}$ & $\begin{array}{l}5 \times 10^{6} \text { cells } \\
20 \times 10^{6} \text { cells }\end{array}$ & Rate of SAE & $\begin{array}{l}\text { - Improve- } \\
\text { ment in } \\
\text { VAS, ODI, } \\
\text { GHS, SF-36, } \\
\text { and narcotic } \\
\text { use question- } \\
\text { naire } \\
\text { - Change in } \\
\text { disc height } \\
\text { at X-ray } \\
\text { - Change in } \\
\text { T2 MRI sig- } \\
\text { nal intensity } \\
\text { within the } \\
\text { NP }\end{array}$ & $24 \mathrm{mo}$ \\
\hline
\end{tabular}


Table 2. Continued.

\begin{tabular}{|c|c|c|c|c|c|c|c|c|c|}
\hline Identifying No. & Year & Design & $\begin{array}{l}\text { No. of } \\
\text { Patients }\end{array}$ & Inclusion Criteria & Cell Source & $\begin{array}{c}\text { Cell } \\
\text { Concentration }\end{array}$ & Primary Outcome & $\begin{array}{l}\text { Secondary } \\
\text { Outcomes }\end{array}$ & $\begin{array}{c}\text { Follow- } \\
\text { Up }\end{array}$ \\
\hline NCT03912454 $4^{75}$ & 2019 & Cohort study & 20 & $\begin{array}{l}\geq 18-60 \text { yo with } \\
\text { chronic LBP }(\geq 3 \\
\text { mo) not } \\
\text { responsive to } \\
\text { conservative } \\
\text { treatment with } \\
\text { single-level IDD } \\
\text { (Pfirrmann }< \\
\text { VII) }\end{array}$ & $\begin{array}{l}\text { Autologous } \\
\text { BMAC }\end{array}$ & & $\begin{array}{l}\text { Improvement in } \\
\text { VAS and ODI }\end{array}$ & $\begin{array}{l}\text { - Patient satis- } \\
\text { faction } \\
\text { - Change in } \\
\text { MRI signal- } \\
\text { ing within } \\
\text { the IVD } \\
\text { - CFU-F } \\
\text { analysis }\end{array}$ & $12 \mathrm{mo}$ \\
\hline NCT04414592 76 & 2020 & Cohort study & 20 & $\begin{array}{l}\geq 18-60 \text { yo with } \\
\text { sciatica due to } \\
\text { unilateral disc } \\
\text { herniation not } \\
\text { responsive to } \\
\text { conservative } \\
\text { treatment } \\
\text { following } \\
\text { endoscopic } \\
\text { lumbar } \\
\text { discectomy }\end{array}$ & $\begin{array}{l}\text { Allogeneic } \\
\text { hUCMSCs }\end{array}$ & $20 \times 10^{6}$ cells & $\begin{array}{l}\text { Change in MRI } \\
\text { signalling within } \\
\text { the IVD }\end{array}$ & $\begin{array}{l}\text { - Improve- } \\
\text { ment in } \\
\text { VAS, ODI, } \\
\text { and SF-36 } \\
\text { - Change in } \\
\text { disc height } \\
\text { at X-ray } \\
\text { - Change in } \\
\text { size of disc } \\
\text { herniation at } \\
\text { MRI } \\
\text { - Rate of SAE }\end{array}$ & $12 \mathrm{mo}$ \\
\hline NCT04499105 $5^{77}$ & 2020 & Cohort study & 10 & $\begin{array}{l}\geq 20-65 \text { yo with } \\
\text { IDD not } \\
\text { responsive to } \\
\text { conservative } \\
\text { treatment }\end{array}$ & $\begin{array}{l}\text { Allogeneic } \\
\text { hUCMSCs }\end{array}$ & Not specified & $\begin{array}{l}\text { Improvement in } \\
\text { VAS and change } \\
\text { in MRI signalling } \\
\text { within the IVD }\end{array}$ & $\begin{array}{l}\text { - Change in } \\
\text { SSEP } \\
\text { - Change in } \\
\text { myelogra- } \\
\text { phy/EMG } \\
\text { - Improve- } \\
\text { ment in ODI }\end{array}$ & $6 \mathrm{mo}$ \\
\hline NCT04759105 $5^{73}$ & 2020 & $\mathrm{RCT}$ & 52 & $\begin{array}{l}\geq 18-65 \text { yo workers } \\
\text { with chronic LBP } \\
(\geq 6 \text { mo) not } \\
\text { responsive to } \\
\text { conservative } \\
\text { treatment with } \\
\text { multilevel (max } 4 \\
\text { levels) IDD } \\
\text { (Pfirrmann III-V) }\end{array}$ & $\begin{array}{l}\text { Autologous } \\
\text { BM-MSCs }\end{array}$ & $\begin{array}{l}15 \times 10^{6} \text { cells } \\
\text { in } 2 \mathrm{~mL}\end{array}$ & $\begin{array}{l}\text { Improvement in } \\
\text { VAS, ODI, SF36, } \\
\text { and WAI }\end{array}$ & $\begin{array}{l}\text { - Change in } \\
\text { MRI signal } \\
\text { intensity } \\
\text { within the } \\
\text { IVD using } \\
\text { MRI spec- } \\
\text { troscopy } \\
\text { - Change in } \\
\text { employment } \\
\text { and work } \\
\text { status } \\
\text { - Rate of SAE } \\
\text { - Medication } \\
\text { usage }\end{array}$ & $24 \mathrm{mo}$ \\
\hline $\begin{array}{l}\text { EudraCT no. } \\
2019-002749- \\
40^{74}\end{array}$ & 2020 & $\mathrm{RCT}$ & 52 & $\begin{array}{l}\geq 18-65 \text { yo with } \\
\text { chronic LBP }(\geq 6 \\
\text { mo) not } \\
\text { responsive to } \\
\text { conservative } \\
\text { treatment with } \\
\text { multilevel (max } 3 \\
\text { levels) IDD } \\
\text { (Pfirrmann III-V) }\end{array}$ & $\begin{array}{l}\text { Autologous } \\
\text { BM-MSCs }\end{array}$ & $\begin{array}{l}15 \times 10^{6} \text { cells } \\
\text { in } 2 \mathrm{~mL}\end{array}$ & $\begin{array}{l}\text { Improvement in } \\
\text { VAS, ODI, and } \\
\text { SF36 }\end{array}$ & $\begin{array}{l}\text { - Change in } \\
\text { T2 MRI sig- } \\
\text { nal intensity } \\
\text { within the } \\
\text { NP } \\
\text { - Change in } \\
\text { employment } \\
\text { and work } \\
\text { status } \\
\text { - Rate of SAE } \\
\text { - Medication } \\
\text { usage }\end{array}$ & $24 \mathrm{mo}$ \\
\hline
\end{tabular}

Abbreviations: ADSCs, adipose-derived stem cells; BM-MSCs, bone marrow-derived mesenchymal stem cells; BMAC, bone marrow aspirate concentrate; CFU-F, colony-forming unit-fibroblast; EMG, electromyography; GHS, Global Health Score; HA, hyaluronic acid; hUCMSCs, human umbilical cord mesenchymal stem cells; IDD, intervertebral disc degeneration; IVD, intervertebral disc; LBP, low back pain; MRI, magnetic resonance imaging; NP, nucleus pulposus; ODI, Oswestry Disability Index; RCT, randomized controlled trial; SAE, serious adverse events; SF36, Short Form Health Survey-36; SSEP, somatosensory evoked potentials; VAS, visual analog scale; WAI, Work Ability Index; yo, years old. 
of pain-relieving medications and variations of the patients' occupational status.

\section{MAIN LIMITATIONS AND FUTURE PERSPECTIVES}

IVD regeneration through the intradiscal administration of stem cells is an attractive approach with promising results as shown by preclinical and early clinical studies. However, several questions still remain unanswered.

Numerous animal studies have depicted the feasibility and the strong regenerative potential of the delivery of stem cells within the degenerated IVD. However, such results cannot be directly translated to humans due to multiple factors, including biomechanical considerations (quadrupeds versus bipeds); different IVD structure, size, and cellularity (higher representation of notochordal cells); and shorter lifespans and unphysiological onset of IDD in animals. ${ }^{26}$

Additional important issues to be addressed are the timing of the treatment from the pain onset, the stage of degeneration to treat, and dosing of implanted cells. Ideally, a regenerative approach is advisable at early stages of IDD, before the development of structural degenerative changes and the complete exhaustion of the local stem cell pool. A study from Maidhof et $\mathrm{al}^{78}$ evaluated the intradiscal administration of MSCs in a rat stab model at 3,14 , or 30 days postinjury in terms of cell fate and glycosaminoglycan synthesis. The results showed that cells transplanted at the earliest time point were retained inside the IVD while in other cases they tended to migrate out from the NP. In addition, MSCs administered at 3 days postinjury increased glycosaminoglycan content more significantly than at other time points. This suggests that MSCs transplanted at earlier stages of IDD may promote stem cell anabolism, while treating more advanced stages of degeneration may blunt the regenerative potential of this approach. Indeed, as IDD progresses, the disc microenvironment becomes increasingly harsher with severe repercussions on both resident and transplanted cells. The endplate undergoes progressive calcification with reduced nutrient diffusion and decreased levels of $\mathrm{O}_{2}$ and glucose. As a consequence, cell metabolism shifts to an anaerobic response, with higher levels of lactic acid and a gradual drop of the local $\mathrm{pH}$. Increased acidity, together with lack of nourishment and tissue inflammation, gradually reduces cell viability and upregulates the expression of metalloproteinases favoring ECM breakdown and disruption of IVD microarchitecture, eventually leading to tissue damage and cellular overstress. ${ }^{15}$ In this regard, as IVD cell density is normally $2-3 \times$ $10^{6}$ cells $/ \mathrm{mL}$ in a normal human disc, increasing local cell concentration by 10-20 times through MSC implantation would increase nutrient demand and ultimately result in competition with the remaining viable IVD cells for available metabolites. In the worst scenario, this would cause the majority of resident cells and implanted MSCs to die. ${ }^{26}$ Therefore, cell concentration should be carefully evaluated before injection based on the degree of IDD.

In addition, the diagnosis of discogenic LBP is intrinsically challenging as many patients suffer from LBP in absence of radiological signs of IDD, as well as many others who show even mildadvanced IDD at MRI but are completely asymptomatic. $^{79}$ Therefore, additional studies are needed in order to refine the diagnosis of discogenic LBP and to identify candidates who would concretely benefit from IVD regeneration with stem cells.

Furthermore, as LBP may notoriously have a strong psychological component susceptible to the placebo effect, ${ }^{80}$ the results from multicenter, prospective RCTs are highly expected in order to define the exact contribution of the regenerative therapy on the perception of LBP. In this regard, the use of validated scales such as the Örebro musculoskeletal pain screening questionnaire and the STarTBack tool, which contain questions about pain duration, emotional distress, fear-avoidance beliefs, self-perceived functioning, and expected return to work, may help assess psychological and social factors that are linked with an understated or overstated response to the treatment. ${ }^{81}$

\section{CONCLUSION}

LBP due to IDD is a pandemic condition with ever-increasing economic and social burdens. IVD regeneration following stem cell transplantation has been proposed as a promising approach to revert degenerative changes owing to the capacity of stem cells to differentiate towards NP-like cells as well as their anti-inflammatory and anticatabolic effects. Several preclinical and early clinical studies have confirmed such proof of concept and provided encouraging results in terms of regenerative effects and LBP reduction, respectively. Definitive out- 
comes from RCTs are now highly expected in order to translate this innovative therapy from bench to bedside. More specifically, developing a safe approach, defining the optimal MSC source, and obtaining a sustained relief from LBP with improvement of disc hydration will be crucial points in the future establishment of a cell therapy for IVD regeneration.

\section{REFERENCES}

1. Walker BF. The prevalence of low back pain: a systematic review of the literature from 1966 to 1998. Clin Spine Surg. 2000;13(3):205-217.

2. Calvo-Muñoz I, Gómez-Conesa A, Sánchez-Meca J. Prevalence of low back pain in children and adolescents: a meta-analysis. BMC Pediatr. 2013:13:14.

3. Hartvigsen J, Hancock MJ, Kongsted A, et al. What low back pain is and why we need to pay attention. Lancet. 2018;391:2356-2367.

4. Vos T, Allen C, Arora M, et al. Global, regional, and national incidence, prevalence, and years lived with disability for 310 diseases and injuries, 1990-2015: a systematic analysis for the Global Burden of Disease Study 2015. Lancet. 2016;388:1545-1602.

5. Chang D, Zygourakis CC, Wadhwa H, Kahn JG. Systematic review of cost-effectiveness analyses in U.S. spine surgery. World Neurosurg. 2020;S1878875020310949. doi:10. 1016/j.wneu.2020.05.123

6. de Schepper EIT, Jurgen D, van Meurs J, et al. The association between lumbar disc degeneration and low back pain: the influence of age, gender, and individual radiographic features. Spine. 2010;35:531-536.

7. Kalichman L, Hunter DJ. The genetics of intervertebral disc degeneration. Associated genes. Joint Bone Spine. 2008;75:388-396.

8. Nasto LA, Ngo K, Leme A, et al. Investigating the role of DNA damage in tobacco smoking-induced spine degeneration. Spine J. 2014;14:416-423.

9. Cannata F, Vadalà G, Ambrosio L, et al. Intervertebral disc degeneration: a focus on obesity and type 2 diabetes. Diabetes Metab Res Rev. 2020;36:e3224. doi:10.1002/dmrr.3224

10. Xu X, Li X, Wu W. Association between overweight or obesity and lumbar disk diseases: a meta-analysis. J Spinal Disord Tech. 2015;28:370-376.

11. Dowdell J, Erwin M, Choma T, Vaccaro A, Iatridis J, Cho SK. Intervertebral disk degeneration and repair. Neurosurgery. 2017;80:S46-S54.

12. Vadalà G, Russo F, Di Martino A, Denaro V. Intervertebral disc regeneration: from the degenerative cascade to molecular therapy and tissue engineering. J Tissue Eng Regen Med. 2015;9:679-690.

13. Iatridis JC, ap Gwynn I. Mechanisms for mechanical damage in the intervertebral disc annulus fibrosus. $J$ Biomech. 2004;37:1165-1175.

14. Clouet J, Fusellier M, Camus A, Le Visage C, Guicheux J. Intervertebral disc regeneration: from cell therapy to the development of novel bioinspired endogenous repair strategies. Adv Drug Deliv Rev. 2019;146:306-324.

15. Vadalà G, Ambrosio L, Russo F, Papalia R, Denaro V.
Interaction between mesenchymal stem cells and intervertebral disc microenvironment: from cell therapy to tissue engineering. Stem Cells Int. 2019;2019:1-15.

16. Hsieh AH, Hwang D, Ryan DA, Freeman AK, Kim H. Degenerative anular changes induced by puncture are associated with insufficiency of disc biomechanical function. Spine. 2009;34:998-1005.

17. Carragee EJ, Don A, Hurwitz E, Cuellar J, Carrino J, Herzog R. 2009 ISSLS prize winner: does discography cause accelerated progression of degeneration changes in the lumbar disc: a ten-year matched cohort study. Spine. 2009;34:23382345.

18. Vadalà G, Russo F, Pattappa G, et al. The transpedicular approach as an alternative route for intervertebral disc regeneration. Spine. 2013;38:E319-E324.

19. Decante C, Clouet J, Hamel A, et al. Collateral effects of targeting the nucleus pulposus via a transpedicular or transannular surgical route: a combined x-ray, MRI, and histological long-term descriptive study in sheep. Eur Spine J. 2020. doi:10. 1007/s00586-020-06602-5

20. Vadalà G, Russo F, Ambrosio L, Loppini M, Denaro V. Stem cells sources for intervertebral disc regeneration. World $J$ Stem Cells. 2016;8:185-201.

21. Liao J-C. Cell therapy using bone marrow-derived stem cell overexpressing BMP-7 for degenerative discs in a rat tail disc model. Int J Mol Sci. 2016;17. doi:10.3390/ijms17020147

22. Blanquer SBG, Gebraad AWH, Miettinen S, Poot AA, Grijpma DW, Haimi SP. Differentiation of adipose stem cells seeded towards annulus fibrosus cells on a designed poly(trimethylene carbonate) scaffold prepared by stereolithography. $J$ Tissue Eng Regen Med. 2017;11:2752-2762.

23. Wang J, Tao Y, Zhou X, et al. The potential of chondrogenic pre-differentiation of adipose-derived mesenchymal stem cells for regeneration in harsh nucleus pulposus microenvironment. Exp Biol Med. 2016;241:2104-2111.

24. Wei J-N, Cai F, Wang F, et al. Transplantation of CXCR4 overexpressed mesenchymal stem cells augments regeneration in degenerated intervertebral discs. DNA Cell Biol. 2016;35:241-248.

25. Peck SH, Bendigo J, Tobias JW, et al. Hypoxic preconditioning enhances bone marrow-derived mesenchymal stem cell survival in a low oxygen and nutrient-limited 3D microenvironment. Cartilage. 2019;1947603519841675. doi:10. $1177 / 1947603519841675$

26. Loibl M, Wuertz-Kozak K, Vadalà G, Lang S, Fairbank J, Urban JP. Controversies in regenerative medicine: should intervertebral disc degeneration be treated with mesenchymal stem cells? JOR Spine. 2019;2:e1043.

27. Wang Z, Cui M, Qui Y, et al. Hypoxia protects rat bone marrow mesenchymal stem cells against compression-induced apoptosis in the degenerative disc microenvironment through activation of the HIF-1 $\alpha /$ YAP signaling pathway. Stem Cells Dev. 2020. doi:10.1089/scd.2020.0061

28. Felka T, Schäfer R, Schewe B, Benz K, Aicher WK. Hypoxia reduces the inhibitory effect of IL- $1 \beta$ on chondrogenic differentiation of FCS-free expanded MSC. Osteoarthritis Cartilage. 2009;17:1368-1376.

29. Binch ALA, Richardson SM, Hoyland JA, Barry FP. Combinatorial conditioning of adipose derived-mesenchymal stem cells enhances their neurovascular potential: implications for intervertebral disc degeneration. JOR Spine. 2019;2:e1072.

30. Zhang Y, Wang Y, Zhou X, et al. Osmolarity controls 
the differentiation of adipose-derived stem cells into nucleus pulposus cells via histone demethylase KDM4B. Mol Cell Biochem. 2020;472:157-171.

31. Sakai D, Nakamura Y, Nakai T, et al. Exhaustion of nucleus pulposus progenitor cells with ageing and degeneration of the intervertebral disc. Nat Commun. 2012;3:1264.

32. Li X-C, Tang Y, Wu JH, Yang PS, Wang DL, Ruan DK. Characteristics and potentials of stem cells derived from human degenerated nucleus pulposus: potential for regeneration of the intervertebral disc. BMC Musculoskelet Disord. 2017; 18:242.

33. Takahashi K, Yamanaka S. Induction of pluripotent stem cells from mouse embryonic and adult fibroblast cultures by defined factors. Cell. 2006;126:663-676.

34. Tang R, Jing L, Willard VP, et al. Differentiation of human induced pluripotent stem cells into nucleus pulposus-like cells. Stem Cell Res Ther. 2018;9:61.

35. Sheyn D, Ben-David S, Tawackoli W, et al. Human iPSCs can be differentiated into notochordal cells that reduce intervertebral disc degeneration in a porcine model. Theranostics. 2019;9:7506-7524.

36. Jung Y, Bauer G, Nolta JA. Concise review: induced pluripotent stem cell-derived mesenchymal stem cells: progress toward safe clinical products. Stem Cells. 2012;30:42-47.

37. Le Maitre CL, Baird P, Freemont AJ, Hoyland JA. An in vitro study investigating the survival and phenotype of mesenchymal stem cells following injection into nucleus pulposus tissue. Arthritis Res Ther. 2009;11:R20.

38. Sakai D, Mochida J, Iwashina T, et al. Differentiation of mesenchymal stem cells transplanted to a rabbit degenerative disc model: potential and limitations for stem cell therapy in disc regeneration. Spine. 2005;30:2379-2387.

39. Richardson SM, Walker RV, Parker S, et al. intervertebral disc cell-mediated mesenchymal stem cell differentiation. Stem Cells. 2006;24:707-716.

40. Vadalà G, Sowa G, Hubert M, Gilbertson LG, Denaro V, Kang JD. Mesenchymal stem cells injection in degenerated intervertebral disc: cell leakage may induce osteophyte formation. J Tissue Eng Regen Med. 2012;6:348-355.

41. Henriksson HB, Papadimitrou N, Hingert D, Baranto A, Lindahl A, Brisby H. The traceability of mesenchymal stromal cells after injection into degenerated discs in patients with low back pain. Stem Cells Dev. 2019;28:1203-1211.

42. Li X, Wu A, Han $\mathrm{C}$, et al. Bone marrow-derived mesenchymal stem cells in three-dimensional co-culture attenuate degeneration of nucleus pulposus cells. Aging. 2019;11:9167-9187.

43. Vadalà G, Studer R, Sowa G, et al. Coculture of bone marrow mesenchymal stem cells and nucleus pulposus cells modulate gene expression profile without cell fusion. Spine. 2008;33:870-876.

44. Vadalà $\mathrm{G}$, Sobajima $\mathrm{S}$, Lee, JY, et al. In vitro interaction between muscle-derived stem cells and nucleus pulposus cells. Spine J. 2008;8:804-809.

45. Hingert D, Nawilaijaroen $\mathrm{P}$, Aldridge J, Baranto A, Brisby $H$. Investigation of the effect of secreted factors from mesenchymal stem cells on disc cells from degenerated discs. Cells Tissues Organs. 2019;208:76-88.

46. Elabd C, Ichim TE, Miller K, et al. Comparing atmospheric and hypoxic cultured mesenchymal stem cell transcriptome: implication for stem cell therapies targeting intervertebral discs. J Transl Med. 2018;16:222.
47. Chen S, Zhao L, Deng X, et al. Mesenchymal stem cells protect nucleus pulposus cells from compression-induced apoptosis by inhibiting the mitochondrial pathway. Stem Cells Int. 2017;2017:1-10.

48. Liu M-H, Bian B-S-J, Cui X, et al. Mesenchymal stem cells regulate mechanical properties of human degenerated nucleus pulposus cells through SDF-1/CXCR4/AKT axis. Biochim Biophys Acta BBA - Mol Cell Res. 2016;1863:19611968.

49. James G, Blomster L, Hall L, et al. Mesenchymal stem cell treatment of intervertebral disc lesion prevents fatty infiltration and fibrosis of the multifidus muscle, but not cytokine and muscle fiber changes. Spine. 2016;41:1208-1217.

50. Risbud MV, Shapiro IM. Role of cytokines in intervertebral disc degeneration: pain and disc content. Nat Rev Rheumatol. 2014;10:44-56.

51. Le Maitre CL, Freemont AJ, Hoyland JA. The role of interleukin-1 in the pathogenesis of human intervertebral disc degeneration. Arthritis Res Ther. 2005;7:R732-745.

52. Johnson ZI, Schoepflin ZR, Choi H, Shapiro IM, Risbud MV. Disc in flames: roles of TNF- $\alpha$ and IL-1 $\beta$ in intervertebral disc degeneration. Eur Cell Mater. 2015:30:104-116; discussion $116-117$.

53. Borem R, Madeline A, Bowman M, Jill S, Tokish J, Mercuri J. Differential effector response of amnion- and adipose-derived mesenchymal stem cells to inflammation; implications for intradiscal therapy. $J$ Orthop Res. 2019;37:2445-2456.

54. Lyu F-J, Cheung KM, Zheng Z, Wang H, Sakai D, Leung VY. IVD progenitor cells: a new horizon for understanding disc homeostasis and repair. Nat Rev Rheumatol. 2019;15:102-112.

55. Miguélez-Rivera L, Pérez-Castrillo S, González-Fernández ML, et al. Immunomodulation of mesenchymal stem cells in discogenic pain. Spine J. 2018;18:330-342.

56. Teixeira GQ, Pereira CL, Ferreira JR, et al. Immunomodulation of human mesenchymal stem/stromal cells in intervertebral disc degeneration: insights from a proinflammatory/degenerative ex vivo model. Spine. 2018;43:E673-E682.

57. Zhao Y, Qin Y, Wu S, et al. Mesenchymal stem cells regulate inflammatory milieu within degenerative nucleus pulposus cells via p38 MAPK pathway. Exp Ther Med. 2020;20:22.

58. Fan $\mathrm{P}, \mathrm{Yu} \mathrm{X}-\mathrm{Y}$, Chen $\mathrm{C}-\mathrm{H}$, et al. Mitophagy is a protective response against oxidative damage in bone marrow mesenchymal stem cells. Life Sci. 2019;229:36-45.

59. Orozco L, Soler R, Morera C, Alberca M, Sánchez A, García-Sancho J. Intervertebral disc repair by autologous mesenchymal bone marrow cells: a pilot study. Transplantation. 2011;92:822-828.

60. Pettine KA, Murphy MB, Suzuki RK, Sand TT. Percutaneous injection of autologous bone marrow concentrate cells significantly reduces lumbar discogenic pain through 12 months. Stem Cells Dayt Ohio. 2015;33:146-156.

61. Pettine K, Suzuki R, Sand T, Murphy M. Treatment of discogenic back pain with autologous bone marrow concentrate injection with minimum two year follow-up. Int Orthop. 2016;40:135-140.

62. Kumar H, Ha D-H, Lee E-J, et al. Safety and tolerability of intradiscal implantation of combined autologous adiposederived mesenchymal stem cells and hyaluronic acid in patients 
with chronic discogenic low back pain: 1-year follow-up of a phase I study. Stem Cell Res Ther. 2017;8:262.

63. Comella K, Silbert R, Parlo M. Effects of the intradiscal implantation of stromal vascular fraction plus platelet rich plasma in patients with degenerative disc disease. $J$ Transl Med. 2017;15:12.

64. Noriega DC, Ardura F, Hernández-Ramajo R, et al. Intervertebral disc repair by allogeneic mesenchymal bone marrow cells: a randomized controlled trial. Transplantation. 2017;101:1945-1951.

65. Elabd C, Centeno CJ, Schultz JR, Lutz G, Ichim T, Silva FJ. Intra-discal injection of autologous, hypoxic cultured bone marrow-derived mesenchymal stem cells in five patients with chronic lower back pain: a long-term safety and feasibility study. J Transl Med. 2016;14:253. doi:10.1186/s12967-0161015-5

66. Amirdelfan K, Bae H, McJunkin T, et al. Allogeneic mesenchymal precursor cells treatment for chronic low back pain associated with degenerative disc disease: a prospective randomized, placebo-controlled 36-month study of safety and efficacy. Spine J. 2021;21(2), 212-230.

67. Chahla J, Mannava S, Cinque ME, Geeslin AG, Codina D, LaPrade RF. Bone marrow aspirate concentrate harvesting and processing technique. Arthrosc Tech. 2017;6:e441.

68. Placebo-controlled Study to Evaluate Rexlemestrocel-L Alone or Combined With Hyaluronic Acid in Subjects With Chronic Low Back Pain. ClinicalTrials.gov identifier: NCT02412735. Updated June 2, 2020. Accessed April 8, 2021. https://clinicaltrials.gov/ct2/show/NCT02412735

69. Bone Marrow Concentrate Intradiscal Injection for Chronic Discogenic Low Back Pain. ClinicalTrials.gov identifier: NCT03340818. Updated January 18, 2020. Accessed April 9, 2021. https://clinicaltrials.gov/ct2/show/NCT03340818

70. Mesenchymal Stem Cells for Lumbar Degenerative Disc Disease. ClinicalTrials.gov identifier: NCT03692221. Updated April 4, 2019. Accessed April 9, 2021. https://clinicaltrials.gov/ ct $2 /$ show/NCT03692221

71. Efficacy of Intradiscal Injection of BM-MSC in Subjects With Chronic Low Back Pain (LBP) Due to Lumbar Degenerative Disc Disease (DDD) Unresponsive (RESPINE). ClinicalTrials.gov identifier: NCT03737461. Updated April 10, 2020. Accessed April 9, 2021. https://clinicaltrials.gov/ct2/ show/NCT03737461

72. Autologous, Culture-Expanded Mesenchymal Stromal Cells for Degenerative Disc Disease. ClinicalTrials.gov identifier: NCT03461458. Updated December 29, 2020. Accessed April 9, 2021. https://clinicaltrials.gov/ct2/show/NCT03461458

73. Efficacy of Intradiscal Injection of Autologous BM-MSC in Worker Patients Affected by Chronic LBP Due to Multilevel IDD (ACTIVE). ClinicalTrials.gov identifier: NCT04759105. Updated February 18, 2021. Accessed April 9, 2021. https:// clinicaltrials.gov/ct2/show/NCT04759105
74. Intervertebral Disc REgeneration mediated by Autologous Mesenchymal stem/stromal cells intradiscal injection: a phase IIB randomized clinical trial (DREAM). EudraCT identifier no. 2019-002749-40. Updated January 18, 2021. Accessed April 9, 2021. https://www.clinicaltrialsregister.eu/ ctr-search/trial/2019-002749-40/IT

75. A Prospective Study of Clinical Outcomes Following a Single Intradiscal Injection of Bone Marrow Aspirate Concentrate (BMAC) for Single Level Discogenic Low Back Pain. ClinicalTrials.gov identifier: NCT03912454. Updated February 29, 2020. Accessed April 9, 2021. https://clinicaltrials.gov/ct2/ show/NCT03912454

76. Human Umbilical Cord Mesenchymal Stem Cells For the Treatment of Lumbar Disc Degeneration Disease. ClinicalTrials.gov identifier: NCT04414592. Updated June 4, 2020. Accessed April 9, 2021. https://clinicaltrials.gov/ct2/show/ NCT04414592

77. Effectiveness and Safety of Mesenchymal Stem Cell (MSC) Implantation on Degenerative Discus Disease Patients (MSC). ClinicalTrials.gov identifier: NCT04499105. Updated August 6, 2020. Accessed April 9, 2021. https://clinicaltrials. gov/ct2/show/NCT04499105

78. Maidhof R, Rafiuddin A, Chowdhury F, Jacobsen T, Chahine NO. Timing of mesenchymal stem cell delivery impacts the fate and therapeutic potential in intervertebral disc repair. $J$ Orthop Res. 2017;35:32-40.

79. Brinjikji W, Diehn FE, Jarvik JG, et al. MRI findings of disc degeneration are more prevalent in adults with low back pain than in asymptomatic controls: a systematic review and meta-analysis. AJNR Am J Neuroradiol. 2015;36:2394-2399.

80. Pach D, Brinkhaus B, Roll S, et al. Efficacy of injections with Disci/Rhus toxicodendron compositum for chronic low back pain - a randomized placebo-controlled trial. PloS One. 2011;6:e26166.

81. Vlaeyen JWS, Maher CG, Wiech K, et al. Low back pain. Nat Rev Dis Primer. 2018;4:52.

Disclosures and COI: None declared.

Corresponding Author: Luca Ambrosio, MD, Via Alvaro del Portillo 200, 00128 Rome, Italy. Phone: +39 062254 11142; Email: luc. ambros@gmail.com.

Published 30 April 2021

This manuscript is generously published free of charge by ISASS, the International Society for the Advancement of Spine Surgery. Copyright $\odot 2021$ ISASS. To see more or order reprints or permissions, see http://ijssurgery.com. 